\title{
A Study of Respiratory Syncytial Virus Outbreak at Postpartum Care Center in Busan, Korea
}

\author{
Su-Jeong Hwang*, Ho-Cheol Yun, Pyeong-Tae Ku, Ju-Hee Sim, Mi-Ok Lee \\ Busan Metropolitan City Institute of Health \& Environment, Busan 46616, Republic of Korea
}

\author{
Corresponding \\ Su-Jeong Hwang, Public Health Researcher \\ Busan Metropolitan City Institute of \\ Health \& Environment, 120, \\ Hambakbong-ro 140 beon-gil, Buk-gu, \\ Busan 46616, Republic of Korea \\ Phone : +82-51-309-2825 \\ Fax : +82-51-309-2829 \\ E-mail : kies98@korea.kr
}

Received : May 25, 2020

Revised : June 24, 2020

Accepted : June 25, 2020

No potential conflict of interest relevant to this article was reported.

Copyright (C) 2020 Journal of Bacteriology and Virology

(C) This is an Open Access article distributed under the terms of the Creative Commons Attribution Non-Commercial License

(http://creativecommons.org/ license/by-nc/3.0/).
Respiratory syncytial virus (RSV) is common cause of acute respiratory infection in infants and young children. Group life in postpartum care centers is easily exposed to infectious diseases in neonates and puerperds immediately after giving birth, and the harm caused by exposure to them is much greater. In particular, respiratory diseases are highly infectious and infections occur in a short period of time. among them, RSV infections are very serious in children under 5 years of age, leading to death. This paper studied an infection of RSV in outbreaks at postpartum care center in Busan. In 4 postpartum care centers, a total of 877 people (390 neonates, 386 puerperds, 106 others) were exposed to RSV outbreak. Of these, there were 73 RSV-positive patients; most of them had cough and runny nose and no fever. We were collected from neonates and puerperds with acute respiratory tract a total of 146 samples (throat swabs). In 51 samples, RSV (43 cases), human rhinovirus (6 cases), human coronavirus NL63 (1 case), and human coronavirus 229E (1 case) were found to be positive and the rest were negative. All 43 RSV positive samples were identified as RSV B. Sequence analysis of the detected strains was performed to confirm the molecular genetic information of RSV. Out of 43 RSV positive samples, 38 samples were successfully sequenced using the $G$ gene, resulting in all of the same genotype BA9. This study provides a better understanding of RSV prevalence patterns and genetic characteristics. It also contributes to the accumulation of epidemiological data and the development of public health and hygiene.

Key Words: Respiratory syncytial virus, Postpartum care centers, Molecular typing, Outbreaks

\section{INTRODUCTION}

우리나라는 출산 후부터 6 주 이내(산욕기)의 기간 동안 산모를 임신전의 상태로 회복시키 는 '산후조리'라는 문화가 있다. 산후조리 초기의 형태는 대부분 가족에 의한 돌봄 형태였 다. 그러나 최근 여성의 사회진출, 핵가족 증가, 병원 분만의 보편화, 고령초산부를 위한 전 문적인 산후관리 요구도 증가, 그리고 산후조리를 도와주던 부모세대의 여건변화 등 사회 적 시대적 환경의 변화로 인하여 가정 내에서의 산후조리가 어려워졌다 (1). 그래서 생겨난 것이 산후조리원이다. 이러한 산후조리원은 1996년 신고제로 개설된 이후 2006년 모자 보건법 개정으로 관리되기 시작하였다. 하지만 산후조리원에서의 집단생활은 감염성 질환 에 쉽게 노출이 되는 경향이 있다. 특히, 호흡기질환은 감염성이 매우 높아 단시간에 쉽게 이환이 되는 특성이 있기 때문에 면역이 저하된 산욕기의 산모와 출생 직후의 신생아에게 는 치명적일 수 밖에 없다. 
보건복지부의 '산후조리원 감염 현황 자료(2018년)'에 따르면, 2014년에서 2018년 동안 산후조리원 내 집단 감염을 일으키는 원인으로 호흡기계 질환(510건, $66.7 \%)$ 이 가장 많은 부분을 차지하며 장관계 질환(24.3\%), 구강칸디다, 뇌수막염 등의 기타질환(9.0\%) 순이 었다. 특히, 호흡기계 질환으로 인한 산후조리원 집단감염 발생은 총 510 건 중 340건(66.7\%)이었고 이 중 259건이 호흡기세포융합바 이러스(respiratory syncytial virus, RSV)에 의한 것이었다 (2). 이렇듯, 매년 RSV 유행시기만 되면 산후조리원에서의 RSV 집단감염이 사회적 이슈가 된다. 그럼에도 불구하고, 산후조리원이 1996년 처음 등장한 이후 전국적으로 564곳(2018년 기준)으로 늘어났으며 출 산한 여성의 $75.1 \%$ 가 육아에 시달리지 않고 편하게 산후조리를 할 수 있다는 이유로 산후조리 시 산후조리원을 이용하는 것으로 나타났 다 (3). 부산의 경우, 산후조리원 총 30개소(2017년 8월 기준)가 운영이 되고 있으며 하루 평균 이용인원 568명, 연간 이용인원은 41,314명이다 (4).

RSV로 인한 집단발생을 처음으로 인지한 사건은 1941년에 Admas가 보고한 것으로 추정이 되는 데, 1937년 미국 minneapolis의 병원 에서 32명의 영아(대부분 4-12주 생) 중 4명이 폐렴으로 사망하였고 이들 모두 RSV 감염의 특징인 기관지 상피세포에서 세포질 합포체 가 발견되었다 (5). RSV는 1955년 감기와 유사한 증상을 보이는 실험실 침팬지의 콧물에서 처음 분리되었고, 분리된 바이러스를 배양하 여 그 배양액을 다시 침팬지 비강에 접종했을 때, 감기유사증상 및 항체 형성이 확인되어 초기에는 chimpanzee coryza agent로 명명되 었다 (6). 이후 후두기관지염과 폐렴증상을 가진 환자에서 분리되어 동물뿐만 아니라 사람에게도 질환을 일으킨다는 것을 확인하고, 조직 배양 상 합포체형 세포병변(syncytial cytopathic effect)이 나타나는 특성이 있어 RSV라 명명되었다 $(6,7)$.

일반적으로 RSV는 전 연령이 감염되는 바이러스로, 그 증상으로는 가벼운 감기 증상부터 기계를 사용하여 인공적으로 공기를 폐 안으로 넣는 등의 행위를 요하는 심각한 증상을 보이다 결국엔 사망에 이르기도 한다 (8). 영유아기의 RSV 감염 시 감염된 환아의 약 20 40\% 는 모세기관염이나 폐렴증상이 있으며 콧물, 미열, 기침, 천식 등의 증상을 보인다고 한다. 그리고 소아기의 RSV 감염은 심각한 급성 하 부 호흡기 감염(acute lower respiratory infections)을 유발하는 것으로 알려져 있다 $(9,10)$. 또한 신생아기의 RSV 감염은 재발성 천 명 및 천식의 발생과 관련이 있다고 하며 RSV의 전형적인 감염증상이 없는 것으로 보고되고 있다 (11). 그래서 산후조리원에서 생활하는 신생아의 경우 RSV 감염 시 전형적인 증상이 없기 때문에 상태를 주의 깊게 살펴보지 않으면 RSV로 인한 집단 감염의 가능성을 항상 내 포하게 된다.

이에 본 연구는 2018년 부산지역의 산후조리원에서 발생한 신생아 RSV 집단감염 사례들의 역학적 특성을 파악하여 산후조리원의 RSV의 감염 및 예방대책을 위한 기초자료가 되고자 한다. 그리고 2017/2018절기에 유행한 RSV의 분자생물학적 특성을 살펴본 후, 국내·외 연구와 비교하여 국내 유행 RSV의 유전적 다양성을 규명하고자 한다.

\title{
MATERIALS AND METHODS
}

\author{
연구대상
}

2018년 부산지역 산후조리원에서 발생한 4건의 RSV 집단감염을 대상으로 연구를 실시하였다. 감염병의 예방 및 관리에 관한 법률 제 4 조에 의거, 감염경로 및 감염증상 등을 파악하기 위하여 역학조사를 실시하였고 역학조사대상자는 첫 증상 발생일에서 최대 10일 이전 (잠복기)부터 전파 차단조치(신생아실 폐쇄)가 이루어진 날까지 산후조리원에 입소한 사람으로 한정하였다. 그리고, 진단을 위하여 RSV 감염증에 부합되는 임상증상을 가진 의심환자들로부터 채취된 인후도찰물을 대상으로 호흡기바이러스 8종 검사를 진행하였다.

\section{핵산추출 및 유전자 진단}

병원체의 핵산은 의심검체 $140 \mu$ 을 QIAamp viral RNA mini QIAcube kit (QIAgen, Hilden, Germany)를 이용하여 제조사의 매뉴 얼에 따라 QIAcube (QIAgen, Hilden, Germany)로 추출하였다. 추출된 핵산은 Multiplex real-time PCR/RT-PCR kit (KoGene BioTech, Seoul, Korea)를 이용하여 adenovirus (ADV), human bocavirus ( $h B \circ V$ ), parainfluenzavirus-1,2,3 (PIV-1, 2, 3), human coronavirus-229E, OC43, NL63 (hCoV-229E, OC43, NL63), respiratory syncytial virus-A,B (RSV-A, B), human metapneumovirus (hMPV), human rhinovirus (hRV), influenzavirus-A/H1N1pdm09, A/H3N2, A/H5N1, B (IFV-A/H1N1pdm09, A/H3N2, A/H5N1, $\mathrm{B})$ 의 8종 16 아형을 대상으로 검사하였다. 핵산을 진단키트에 첨가한 후, 실시간 유전자 증폭기 ABI 7500 Fast System (Applied Biosystems, Foster City, CA, USA)를 이용하여 해당 매뉴얼에 따라 유전자 진단을 진행하였다. 
Table 1. List of primers used in this study

\begin{tabular}{clccc}
\hline Primer & \multicolumn{1}{c}{ Sequence (5'-3') } & Application & Target genes & Reference \\
\hline G (151-173)F & CTG GCA ATG ATA ATC TCA ACT TC & One-step & \multirow{2}{*}{ G } & \multirow{2}{*}{ [12] } \\
F (3-22)R & CAA CTC CAT TGT TAT TTG CC & RT-PCR & & \\
\hline
\end{tabular}

\section{유전자 염기서열 분석}

RSV의 염기서열 분석을 위해서 DiaStar 2X OneStep RT-PCR Pre-Mix Kit (SolGent, Daejeon, Korea)로 conventional RT-PCR을 수행하였다. 사용한 primer는 Table 1과 같다. PCR 반응은 $50^{\circ} \mathrm{C} 30$ 분 1회로 CDNA를 합성 한 후, $95^{\circ} \mathrm{C} 15$ 분 1 회, $95^{\circ} \mathrm{C} 20$ 초, $54^{\circ} \mathrm{C} 40$ 초, $72^{\circ} \mathrm{C} 1$ 분 40 회, $72^{\circ} \mathrm{C} 5$ 분의 조건으로 실시하였다 (12). PCR 산물은 $1 \%$ agarose gel (Invitrogen, Waltham, MA, USA)에서 전기 영동 하였고 결과는 Image analyzer (Geldoc XR image system, BIO-RAD, Hercules, CA, USA)로 PCR band를 확인하였다.

PCR 증폭산물을 염기서열분석(Macrogen, Seoul, Korea)을 의뢰하여 확인된 분석된 염기서열은 NCBI (National Center for Biotechnology Information)의 BLAST (Basic Local Alignment Search Tool)를 이용하여 GenBank database에 등록되어 있는 기존에 보고된 표준 주 염기서열과 상동성을 확인하였으며, ClustalX (Toby Gibson EMBL, Heidelberg, Germany)를 이용하여 유전자 거리 측정과 multiple alignment를 수행하였다. 계통분석은 MEGA (Molecular Evolutionary Genetic Analysis) software (version 4.0, Arizona State University, Tempe, USA)를 사용하여 Maximum composite likelihood의 근린결합분석(neighbor-joining: NJ)방법으로 시행하였다. 계통수 분지에 대한 지지도 측정을 위하여 부스트랩(bootstrap)값을 1,000회 반복하였다.

기존에 보고된 문헌을 참고하여 28개의 표준주와 본 연구에서 확인한 RSV의 염기서열을 비교하였다 (13-15).

\section{RESULTS AND DISCUSSION}

\section{집단발생의 역학적 분석}

2018년 부산시 관내에서 발생한 4건의 집단발생 의심환자군을 대상으로 사례를 조사한 결과, $\mathrm{A}$ 산후조리원에서는 노출인원 100 명중 RSV 양성자가 3명(3.0\%), B 산후조리원에서는 노출인원 210명 중 34명(16.2\%), C 산후조리원에서는 노출인원 245명 중 8명 (3.3\%), D 산후조리원에서는 노출인원 322명 중 28 (8.7\%)명으로 확인되었다(Table 2). A D의 산후조리원에서 RSV가 검출된 환자 는 총 73 명이었으며 이들 중 입원환자는 52 명, 외래환자 20 명, 무증상자는 1 명으로 나타났다. 또한 입원환자들의 입원기간은 짧게는 3 일, 길게는 43일이었으며 평균 입원일은 9일이었다(Table 3). 4곳의 산후조리원 중 B 산후조리원에서 발병률이 높게 나왔는데 이 곳은 임산부실이 44개(A: 22개. C: 50개, D: 39개)로 비교적 많은 인원을 수용할 수 있는 곳이기도 하였고 이 시기(2018년 2월 말에서 3월 초)에 전국적으로 RSV의 검출률이 높았던 것으로 확인되어 그 영향이 미친 것으로 보인다.

Table 2. The summary of the outbreaks

\begin{tabular}{cccccc}
\hline \multicolumn{1}{c}{ Group } & Group A & Group B & Group C & Group D & Total \\
\hline Exposed persons & 100 & 210 & 245 & 322 & 877 \\
Neonates & 42 & 92 & 105 & 151 & 390 \\
Puerperds & 42 & 91 & 105 & 148 & 386 \\
The others & 16 & 27 & 35 & 23 & 106 \\
Suspected patients & 10 & 54 & 23 & 99 & 186 \\
No. of RSV detection & 3 & 34 & 8 & 28 & 73 \\
RSV-attack rate (\%) & 3.0 & 16.2 & 3.3 & 8.7 & 9.0 \\
\hline
\end{tabular}

RSV: respiratory syncytial virus 
Table 3. Medical care utilization characteristics of respiratory syncytial virus positive patients

\begin{tabular}{cccc}
\hline & No. of cases (\%) & Characteristics \\
\hline Inpatients & & Minimum and maximum duration of hospitalization (day) & $3-43$ \\
& $52(71.2)$ & Mean duration of hospitalization (day) & 9 \\
Outpatients & $20(27.4)$ & Hospitalization $>7$ days (No.) & 30 \\
Asymptomatic patient & $1(1.4)$ & - \\
total & $73(100)$ & - \\
\hline
\end{tabular}

RSV 집단발생이 일어난 산후조리원에서의 감염병 발생신고는 대부분 RSV 감염 최초발생 이후 3 5일 이내에 이루어졌다. 그러나 D 산 후조리원의 경우, 비슷한 호흡기 증상이 신생아들에게 지속적으로 발생했음에도 불구하고 산후조리원 내부에서는 감염병 발생을 인지 하 지 못하였다. 오히려, 커뮤니티를 통하여 사례가 공유된 부모들이 신고를 주관한 케이스이다. 그래서 적절한 시기에 조치가 취해지지 않 아 RSV에 노출된 인원이 가장 많았고 발병률이 두 번째로 높은 것으로 나타났다.

산후조리원에서의 RSV 집단발생 원인으로는 시설부분과 운영부분에서 살펴볼 수가 있었다. 시설부분으로는, 모성의 보호화 자녀의 건강 에 관하여 필요한 사항을 규정한 법률인 모자보건법의 시행규칙 별표 3에는 '산후조리원의 인력 및 시설기준(제 14조 관련)에 따라 영유 아실 공용면적(세면대, 목욕을 위한 곳, 수유를 준비하는 곳 등 영유아의 개인용 공간이 아닌 곳을 말함)을 제외한 영유아실의 면적은 영 유아 1명당 $1.7 \mathrm{~m}^{2}$ 이상이어야 한다'고 명시되어 있다. 그러나 이 조항에는 2017년 7월 1일 이전에 산후조리업을 신고한 산후조리원은 해당되지 않는다. 본 연구에서 집단발생 한 산후조리원 4곳 모두 2017년 7월 1일 이전에 설립되었기 때문에 신생아 요람(bassinet) 간 의 공간이 충분히 확보되지 않은 것으로 확인되었다. 이는 비말전파 예방을 위한 침상 간 공간이 확보되지 않은 것을 의미하며 신생아 간 의 비말 전파로 인한 RSV 감염 가능성을 배제할 수 없다.

운영부분으로는 산후조리원에서 bassinet 운영 시, 새로 들어오는 신생아나 퇴실하는 신생아 수에 따라 그 위치가 수시로 이동되는 등 위 치가 고정되어 있지 않다는 것이다. 이는 2017년 7월 변경된 산후조리원의 시설기준을 따라 영유아 개개인의 공간을 확보한다고 하더라 도 bassinet 위치가 수시로 이동된다면 감염병 발생 시 전파 범위가 넓어져 집단발생의 규모가 커질 수 밖에 없다. 그리고 상주의사의 부 재가 또 다른 원인이 될 수 있다. 4건의 집단발생에서 RSV에 감염된 신생아 $70 \%$ 이상이 산후조리원을 퇴원한 후 근처 대학병원이나 비 교적 큰 규모의 종합병원에 입원했다. 산후조리원은 의료시설이 아니기에 상주의사가 없다. 그렇기 때문에 신생아의 상태를 면밀하게 관 찰하고 진료하는 부분은 부족할 수 밖에 없다.

\section{임상증상에 따른 분석}

RSV 양성자의 증상을 확인한 결과 발열, 콧물, 코막힘, 기침, 재채기, 천명, 숨가쁨. 가래, 쉰 목, 폐렴 등을 보였으며, 주 증상으로는 기침, 콧물, 코막힘으로 나타났다(Table 4). 전 연령을 대상으로 RSV의 임상증상 특성을 확인한 기존 연구에서는 주 증상은 발열이었으며, 기 침, 콧물, 가래가 유의성이 있는 것으로 보고하고 있다 (16). 본 연구에서도 기침과 콧물은 주요 증상으로 보였으나 발열의 경우, RSV 양 성자(70명) 중 5명 $(7.1 \%)$ 에서만 나타났다. 발열을 나타낸 환자는 주로 산모로 확인되며, RSV 양성자 중 많은 부분을 차지하는 신생아 에서는 발열은 주 증상이 아닌 것으로 판단된다. 신생아를 대상으로 진행한 국내 연구에서도 RSV 감염 환아에서 나타나는 흔한 임상증상 은 기침이었으며 발열은 거의 없는 것으로 보고하였다 (11). 이러한 특성으로 보아 RSV 유행시기에는 산후조리원 내 신생아에서 발열이 없고 경미한 호흡기 증상을 나타낸다면, RSV 감염여부 확인이 필요할 것으로 보인다.

\section{병원체 검출 현황}

2018년 부산시 관내에서 발생한 4건의 집단발생 의심환자군 중 146건의 검체를 수집하였다. 이들 중 RSV가 확인된 검체는 43건으로 모두 RSV-B으로 확인되었다. 그리고 hRV가 6건, hCoV가 2건 검출되었다(Table 5). hRV는 급성호흡기감염증을 일으키는 주요 바이러 스 중의 하나이며 IFV 유행 시기에는 검출률이 현저하게 떨어지나 연 중 검출되는 바이러스이다. hCoV는 비교적 동절기에 검출되며, 아 형별 계절특이성은 비교적 없는 것으로 알려져 있다 (17). 
Table 4. Symptom-wise distribution of patients

\begin{tabular}{|c|c|c|c|c|c|}
\hline \multirow[b]{2}{*}{ Symptom } & \multicolumn{4}{|c|}{ No. of patients } & \multirow{2}{*}{$\begin{array}{c}\text { Total } \\
(n=73)\end{array}$} \\
\hline & $\begin{array}{c}\text { Group A } \\
(n=3)\end{array}$ & $\begin{array}{c}\text { Group B } \\
(n=34)\end{array}$ & $\begin{array}{c}\text { Group C } \\
(\mathrm{n}=8)\end{array}$ & $\begin{array}{c}\text { Group D } \\
(\mathrm{N}=28)\end{array}$ & \\
\hline Fever $\left(>38^{\circ} \mathrm{C}\right)$ & - & 1 & 1 & 3 & $5(6.8 \%)$ \\
\hline Runny nose & 1 & 18 & 8 & 19 & $46(63.0 \%)$ \\
\hline Nasal obstruction & 2 & 7 & 2 & 11 & $22(30.1 \%)$ \\
\hline Cough & 3 & 30 & 8 & 19 & $60(82.2 \%)$ \\
\hline Sneezing & - & 6 & 2 & 5 & $13(17.8 \%)$ \\
\hline Wheezing & - & 5 & - & - & $5(6.8 \%)$ \\
\hline Dyspnea & 1 & 1 & 1 & - & $3(4.1 \%)$ \\
\hline Sputum & 1 & 5 & - & - & $6(8.2 \%)$ \\
\hline Sore throat & - & 1 & - & - & $1(1.4 \%)$ \\
\hline Pneumonia & - & - & - & 3 & $3(4.1 \%)$ \\
\hline
\end{tabular}

Table 5. Detection status of respiratory pathogens

\begin{tabular}{cccccccccc}
\hline & Total & ADV & hBoV & PIV & RSV & IFV & hCoV & hRV & hMPV \\
\hline No. of detection & 51 & 0 & 0 & 0 & 43 & 0 & 2 & 6 & 0 \\
$\%$ & 34.9 & 0.0 & 0.0 & 0.0 & 29.5 & 0.0 & 1.4 & 4.1 & 0.0 \\
\hline
\end{tabular}

ADV: adenovirus, hBoV: human bocavirus, PIV:parainfluenza virus, RSV: respiratory syncytial virus, IFV: influenzavirus, hCoV: human coronavirus, hRV: human rhinovirus, hMPV: human metapneumovirus,

$\mathrm{hRV}$ 와 hCoV가 검출되었음에도 불구하고 RSV로 인한 집단감염만 발생한 이유로 RSV의 잠복기가 2 8일로 hRV나 hCoV에 비하여 비 교적 길고 호흡기증상이 나타나기 수일 전부터 바이러스를 배출할 수 있기 때문인 것으로 판단된다. 또한, RSV 집단발생이 확인된 시기 가 1 3월 사이로 RSV 유행시기(주로 10월에서 이듬해 3월)가 일치함에 따른 것으로도 보인다.

\section{HRSV의 염기서열 분석 및 계통분석}

RSV는 Paramyxoviridae 과, pneumovirinae 아과, Pneumovirus 속에 속하며 비분절, lipid envelop으로 둘러싸인 단일가닥 negativesense RNA 바이러스이다 (18). 그리고 11개의 단백질을 암호화하는 10 개의 유전자들을 지니고 있는데, 이 중 표면 당단백질인 G단백 질과 F단백질의 항원적 차이에 의해 RSV-A와 RSV-B의 두 개의 혈청형으로 나뉜다 (19). F 단백질은 변이가 적은 반면, G 단백질은 고변 위부위(hypervariable region)가 존재하고 있어 G 단백질을 인코딩하는 G 유전자는 변이가 큰 편이다 (12). 본 연구에서도 RSV 염기서 열 분석을 위하여 $\mathrm{G}$ 유전자를 target으로 하였고 $\mathrm{G}$ gene C-terminal 부위의 두 번째 hypervariable region (second variable region, SVR)을 증폭하였다.

146 건의 RSV 의심환자 검체를 검사한 결과, RSV가 확인된 건은 43건이었으며. 이 중 38건만이 유전자 증폭이 되었다. RSV는 동절기에 유행하는 바이러스로, RSV의 발생양상 등의 추이를 파악할 때는 주로 절기로 확인한다. 2017/2018절기에 해당하는 본 연구에서 확인 된 38건의 RSV-B의 염기서열을 분석한 결과, 모두 BA9 genotype로 확인되었으며 전체적으로 기존에 보고된 분리주와 93.9 99.2\%의 상동성을 보였다. 그리고 Yun (15)의 연구를 통하여 표준주로 등록된 3개의 BA 9 genotype (MK947354, MK947338, MK947344) 과 본 연구에서 확인된 분리주가 같은 범주로 묶이는 것으로 확인되었다(Fig. 1). 이는 Yun (15)의 표준주와 본 연구의 분리주가 같은 절 기인 2017/2018절기에 분리되었기 때문으로 분석된다.

RSV-B는 G 단백질에서의 항원과 게놈 서열의 차이에 따라 35개의 genotype (GB1-13, BA1-14, CB-B, SAB1-4, THB, URU1-2)이 존 재한다 (20). 이 중 BA genotype은 1999년도에 부에노스아이레스에서 첫 분리 되어 전 세계적으로 가장 많은 비중을 차지하고 있으며, G gene 의 C-terminal 부분에 60개의 nucleotide duplication을 포함하는 genotype이다 (21). BA genotype은 현재까지 14개의 


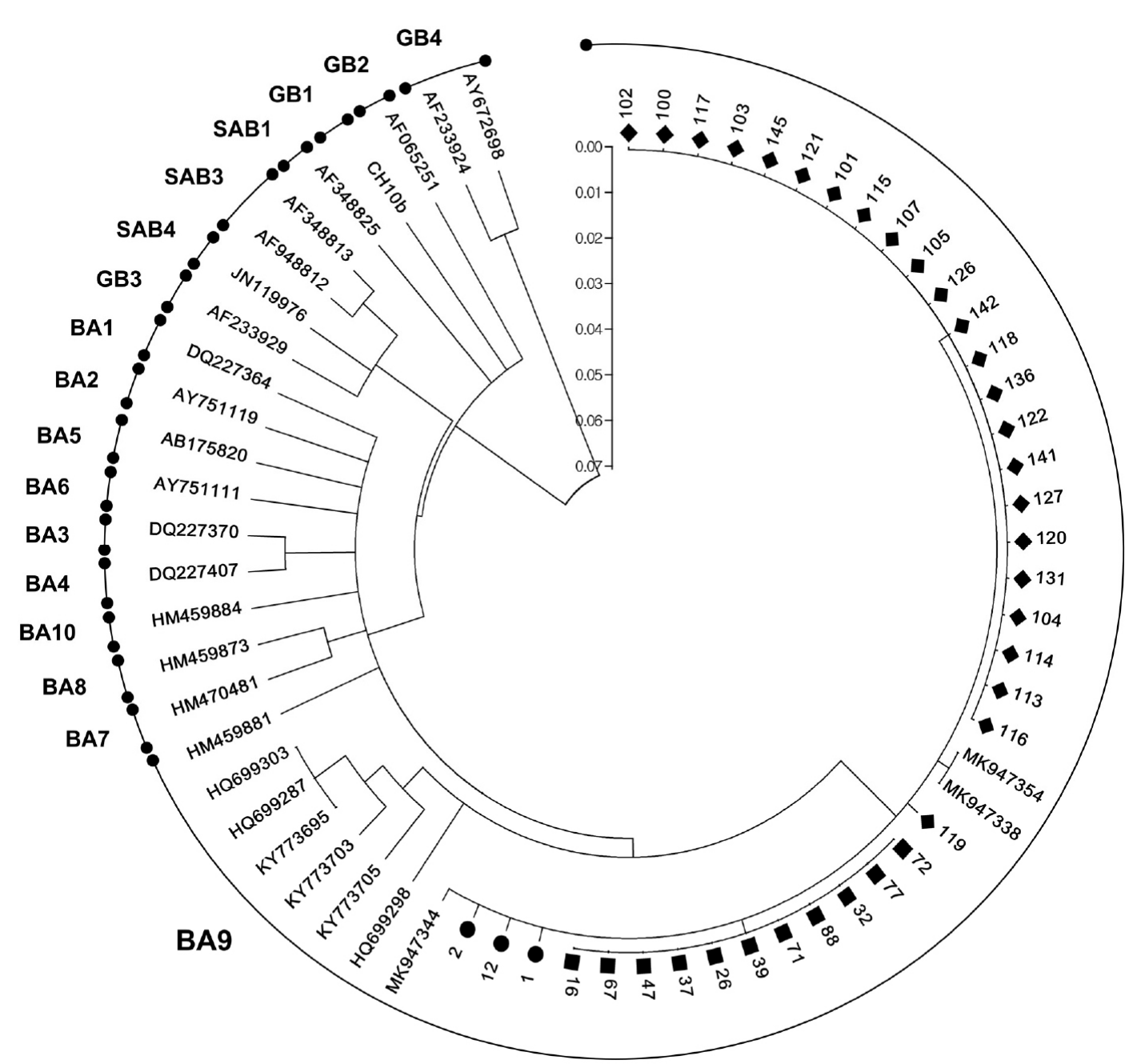

Fig. 1. Phylogenetic trees for RSV-B based on the second hypervariable region of the $G$ protein. Trees using the neighborjoining method with maximum composition likelihood in MEGA 4. Bootstrap values were 1,000 iterations. Sample collected from different groups are indicated by symbols as follows: $\bullet$, B group; $\bullet, C$ group; $\mathbf{\square}, \mathrm{D}$ group.

genotype 으로 분류되어 있으며 (20), 본 연구에서 확인된 BA9 genotype은 BA4 genotype에서 재 분류 된 genotype 으로 일본에서 $2006 / 2007$ 절기에 채취된 호흡기 검체에서 처음 확인되었다 (22). 국내에서는 2005/2006절기 (15), 중국 2006년 (23)에 확인 된 것 으로 보고하고 있다.

국내에서 진행된 RSV genotype 연구 초기에는 RSV의 F 및 SH gene 부위의 염기서열을 기존 분리주와 비교 분석하는 방법 (24)이나 G 단백질에 대한 제한효소에 의한 절단 양상에 따라 유전자형을 확인하는 방법으로 이루어졌다 (14). 그래서 이 시기의 연구는 $G$ 유전자의 SVR 부분을 증폭하여 분석한 본 연구와 비교하기에는 제한적인 부분이 있다. 하지만 이후 연구부터는 G 유전자를 분석하는 연구가 주를 이루었는데 2008/2009 절기에 RSV-B BA9 genotype과 BA10 genotype이 유행하였으며 (15, 25), 2010/2011, 2013/2014절기에 는 BA4 $(16,26)$ 나 BA9가, 2015/2016절기부터는 지속적으로 BA9가 유행하는 것으로 보고하고 있다 $(15,20)$. 그리고 최근 1990년 부터 2018년까지 28년 동안 HRSV의 분자역학적 연구를 진행한 바에 의하면, 1990/1991절기부터 1998/1999절기 까지는 RSV B-SAB2, GB4, GB2 형이 확인되었고 1999/2000절기에서 2005/2006절기에는 다양한 유전자형이 있었으나 주 우점종은 GB3이었으 며, 이후 절기에서부터는 BA9가 주로 유행하는 것으로 밝혔다 (15). 국내에서 진행된 기존의 여러 연구로 보아 2006/2007절기부터는 RSV-B BA genotype 만이 유행하는 것으로 보이며, 본 연구에서도 BA genotype만 확인되어 일치하는 것으로 나타났다 
4건의 RSV 집단발생으로 알아본 바에 따르면, 영유아의 개인용 공간이 확보되지 않은 2017년 7월 이전에 신설된 산후조리원의 경우 운 용 가능한 면적 자체가 넓지 않았다. 그러므로 신생아실 내 냉 - 난방기 가동 시 실내 기온의 편차 발생이나 신생아의 입 · 퇴원이나 재원일 수를 감안하여 bassinet의 위치를 변경하는 등의 운영 방식을 제한하기에는 한계가 있는 것으로 보였다. 또한 상주의사의 부재는 간과할 수 없는 문제점으로 확인되었다. 그렇기 때문에 RSV 유행시기에는 의료관련감염 표준예방지침에 따라 표준주의와 접촉주의를 철저하 게 적용하는 것이 필요하다. 호흡기 증상이 있는 의료진 및 종사자의 근무를 제한하는 등의 호흡기감염 예방 감염관리 수칙을 철저하게 따르는 것이다. 그리고 신생아의 경우 발열 없이 경미한 호흡기증상을 보이는 등의 RSV로 인한 감염이 의심이 된다면 증상을 보이는 환자는 즉시 격리하여 확산을 방지하고 노출된 인원을 파악하여 RSV 진단 검사 등의 적절한 조치가 이루어질 수 있도록 신속하게 대응 하여야 한다.

RSV 유전자 분석을 통하여, RSV-B의 주요 유행 genotype은 BA genotype 인 것으로 확인하였고 모두 BA9 genotype이었다. 이 아형 은 전 세계적으로 널리 퍼져 있는 유전형으로 G gene의 60 개 nucleotide duplication가 BA9 genotype의 진화에 이점을 주기 때문에 숙주 면역반응의 회피를 유도하여 세계적인 분산 및 전파에 기여하는 것으로 보고 있으며 진화속도도 다른 genotype에 비해 빠른 것으 로 알려져 있다 (23).

본 연구는 '부산’이라는 지역적인 제한점과 '2017/2018절기'에만 국한되어 있는 시기적인 제한점이 있다. 그러므로 광범위한 지역과 연 속된 여러 절기를 대상으로 지속적으로 연구하여 RSV의 특성을 파악하는 노력이 필요할 것으로 판단된다. 하지만 이런 제한점에도 불구 하고 본 연구는 산후조리원에서 발생하는 RSV 집단발생 감염관리 대책 마련과 진단제제, 치료제 및 백신개발 등의 감염예방 대책 마련에 중요한 기초자료로 활용될 수 있을 것으로 기대한다.

\section{REFERENCES}

1) Choi HK, Jung NM. Factors Influencing Health Promoting Behavior in Postpartum Women at Sanhujoriwon. Korean J Women Health Nurs 2017:23:135-44.

2) http://www.ipharmnews.com/news/view.php?no=39018

3) http://www.mohw.go.kr/react/jb/sjb030301vw.jsp

4) http://www.busan.go.kr

5) Adams JM. Primary virus pneumonitis with cytoplasmic inclusion bodies; study of an epidemic involving thirty-two infants, with nine deaths. JAMA 1941:116:925-33.

6) Blount RE Jr, Morris JA, Savage RE. Recovery of cytopathogenic agent from chimpanzees with coryza. Proc Soc Exp Biol Med 1956:92:544-9.

7) Chanock R, Roizman $B$, Myers R. Recovery from infants with respiratory illness of a virus related to chimpanzee coryza agent (CCA). I. Isolation, properties and characterization. Am J Hyg 1957:66:281-90.

8) Stensballe LG, Devasundaram JK, Simoes EA. Respiratory syncytial virus epidemics: the ups and downs of a seasonal virus. Pediatr Infect Dis J 2003;22:S21-S32.

9) Borchers AT, Chang C, Gershwin ME, Gershwin LJ. Respiratory Syncytial Virus-a Comprehensive Review. Clin Rev Allergy Immuno/ 2013;45:331-79.

10) Nair H, Nokes DJ, Gessner BD, Dherani M, Madhi SA, Singleton RJ, et al. Global burden of acute lower respiratory infections due to respiratory syncytial virus in young children: a systematic review and meta-analysis. Lancet 2010;375:1545-55.

11) Fauroux $B$, Simões EAF, Checchia PA, Paes $B$, Figueras-Aloy J, Manzoni $P$, et al. The burden and long-term respiratory morbidity associated with respiratory syncytial virus infection in early childhood. Infect Dis Ther 2017:6:173-97. 
12) da Silva LHA, Spilki FR, Riccetto AGL, de Almeida RS, Baracat ECE, Arns CW. Genetic variability in the G protein gene of human respiratory syncytial virus isolated from the Campinas metropolitan region, Brazil. J med Virol 2008:80:1653-60

13) Park E, Park PH, Huh JW, Yun HJ, Lee HK, Yoon MH, et al. Molecular and clinical characterization of human respiratory syncytial virus in South Korea between 2009 and 2014. Epidemiol Infect 2017;145:3226-42.

14) Choi $\mathrm{EH}$, Lee HJ. Genetic diversity and molecular epidemiology of the $G$ protein of subgroups $A$ and $B$ of respiratory syncytial viruses isolated over 9 consecutive epidemics in Korea. J Infect Dis 2000;181:1547-56.

15) Yun KW, Choi EH, Lee HJ. Molecular epidemiology of respiratory syncytial virus for 28 consecutive seasons (1990-2018) and genetic variability of the duplication region in the $\mathrm{G}$ gene of genotypes ON1 and BA in South Korea. Arch Viro/2020;165:1069-77.

16) Hwang SJ, Park DJ, Gu PT, Koo HS, Lee MO. Characteristics of Respiratory Syncytial Virus isolated from Acute Respiratory Infectious Disease in Busan. J Bacterio/ Viro/2016:46:173-80.

17) KCDC. The prevalence of the respiratory viruses in the patients with acute respiratory infections 2014. Public Health Weekly Report 2016:9:26-36.

18) Crowe JE Jr, Williams JV. Immunology of viral respiratory tract infection in infancy. Paediatr Respir Rev 2003;4:112-9.

19) Kim YJ, KIM DW, Lee WJ, Yun MR, Lee HY, Lee HS, et al. Rapid replacement of human respiratory syncytial virus $A$ with the ON1 genotype having 72 nucleotide duplication in G gene. Infect Genet Evo/2014;26:103-12.

20) Yang EA. G gene Analysis of Respiratory Syncytial Virus in Children with Acute Lower Respiratory Tract Infection. Doctoral thesis, Chungnam University 2016.

21) Trento A, Galiano M, Videla C, Carballal G, Garcia-Barreno B, Melero JA, et al. Major changes in the $G$ protein of human respiratory syncytial virus isolates introduced by a duplication of 60 nucleotides. J Gen Viro/2003:84:3115-20.

22) Dapat IC, Shobugawa Y, Sano Y, Saito R, Sasaki A, Suzuki Y, et al. New genotypes within respiratory syncytial virus group B genotype BA in Niigata, Japan. J Clin Microbio/2010;48:3423-7.

23) Song J, Wang H, Shi J, Cui A, Huang $Y$, Sun L, et al. Emergence of BA9 genotype of human respiratory syncytial virus subgroup B in China from 2006 to 2014. Sci Rep 2017;7:16765.

24) Kwon SY, Choi YJ, Kim SY, Song KJ, Lee YJ, Choi JO, et al. Sequence and Phylogenetic Analysis of Respiratory Syncytial Virus Isolated from Korea. J Korean Soc Virol 1996;26:9-22.

25) Baek YH, Choi EH, Song MS, Pascua PNQ, Kwon HI, Park SJ, et al. Prevalence and genetic characterization of respiratory syncytial virus (RSV) in hospitalized children in Korea. Arch Viro/2012:157:1039-50.

26) Park SM. Analysis of Epidemioloigical Characterization and Genetic Diversities for Respiratory Syncytial Virus in Chungnam Korea, Doctoral thesis, Chungnam University 2016. 